\title{
Restitution Without Context: An Examination of the Losing Contract Problem in the Restatement (Third) of Restitution
}

William J. Woodward Jr.

Santa Clara University School of Law, wwoodward@scu.edu

Follow this and additional works at: http://digitalcommons.law.scu.edu/facpubs

Part of the Law Commons

\section{Automated Citation}

William J. Woodward Jr., Restitution Without Context: An Examination of the Losing Contract Problem in the Restatement (Third) of Restitution (2014),

Available at: http://digitalcommons.law.scu.edu/facpubs/849 
A later, edited version of this article is part of a collection assembled into a book, REVISITING THE CONTRACTS SCHOLARSHIP OF STEWART MACAULAY ON THE EMPIRICAL AND THE LYRICAL edited by Jean Braucher, John Kidwell and William C. Whitford published in 2013 by Hart Publishing. The book may be found at http://www.hartpub.co.uk/Search.aspx?Type=2\&Text=Macaulay.

\title{
Restitution Without Context: An Examination of the Losing Contract Problem in the Restatement (Third) of Restitution
}

\author{
William J Woodward, Jr
}

\section{Introduction}

In his 1959 article 'Restitution in Context', Stewart Macaulay reviewed a casebook on restitution and wondered whether the subject could be considered by itself, outside of the far broader context in which restitution cases usually arise. Thus began a long career of considering legal phenomena within their broader settings: without context, one might well lose nuance essential to understanding a subject.

\footnotetext{
* Many thanks go to Alice Abreu, Rick Greenstein, Greg Mandel and Amy Sinden for their comments on an earlier draft and to the late John Kidwell for his extensive support and editing help with earlier drafts. The author also thanks Temple University for research support.
} 
In 2011, restitution was once again isolated as a subject, this time by the American Law Institute, which gave final approval to a Restatement (Third) of Restitution of Restitution and Unjust Enrichment (hereinafter R3RUE). Thus culminated a very long project of identifying a field for 'restating', reviewing the cases and commentary about the field, drafting black letter and commentary, and securing approval for the project from the membership of the American Law Institute. ${ }^{1}$

This Restatement project offers an opportunity to revisit the insights about the importance of context that Macaulay made in 1959. The focus here will be on a particularly difficult contract remedies problem where contract law and restitution historically have been thought to overlap - the losing contract problem. Simply stated, can a person who has made a losing contract (contracting to give more than he will get) recover damages for breach that disregard a loss on the bargain, the risk of which the nonbreacher implicitly agreed to when he made the contract. $R 3 R U E$ treats that problem very differently from the treatment given to the same problem by the Restatement (Second) of Contracts. My contention is that if we examine this same problem through a variety of contexts - real, experimental, theoretical, and practical - the solution proposed by the new Restatement may lack normative support, but it will, nonetheless, be very hard to predict whether it will appeal to the judiciary, which is, after all, the audience to whom a Restatement provision is primarily directed.

Section I will introduce the $R 3 R U E$ project, lay out the losing contract problem using a simple hypothetical, and then briefly outline different approaches to it, including the complex solution proposed in the new Restatement of Restitution. Section II will then consider the problem in the wider contexts of actual, observed contracting behaviour pioneered by Stewart Macaulay and of newer work that examines how experimental subjects regard contract obligation and breach. Both of these contexts reveal a 'reciprocity

\footnotetext{
${ }^{1}$ The process of creating a Restatement is described in M Shapo, 'In Search of the Law of Products Liability: The ALI Restatement Project' (1995) 48 Vanderbilt Law Review 631.
} 
norm' that may animate the behaviour of those who make and perform contracts. When used as a starting point in a normative instrumental analysis of the problem, the reciprocity norm can produce outcomes at odds with a conventional parallel analysis that does not take that norm into account.

Section III will situate this problem within a different context: contract doctrine itself. R3RUE regards the losing contract problem as having a 'contract solution' and proceeds to define that solution using a particular vision of contract law. This conception is sharply distinguished from the broad idea of restitution that otherwise animates $R 3 R U E$, and this particular vision takes scant account of the reciprocity that is endemic to all but a narrow range of contracts. Section III will conclude by showing that this particular vision of contract law contributes strongly to the solution to the losing contract problem found in $R 3 R U E$ and that a different vision, one that takes greater account of reciprocity, may well account for the different treatment given to the same problem in the Restatement (Second) of Contracts.

Having suggested that our views about contract law may have changed during the 30 years between these restatement projects and that those views may well contribute to the different solutions to the same problem that we find in those two Restatement projects, we come to the uneasy conclusion in Section III that the 'right' solution as a normative matter may depend on how one looks at the problem and, in particular, on the extent to which we believe that the reciprocity norm is an important one in contract law.

Finally, Section IV will consider how the new rule might be received in the world of the courts as well as whether it might have effects outside the litigation system. Here it will be suggested that the rule may actually operate differently from the rule supported by most of the supporting commentary in $R 3 R U E$. This will result in substantial uncertainty that could in turn have the unintended effect (if it has any effects at all) of motivating the parties to modify their ongoing contracts rather than face the uncertainties of litigation. In this respect, the 'success' of the new rule will be in the eye of the beholder. 


\section{The Losing Contract Problem and R3RUE's Proposed Solution}

At its Annual Meeting in 2010 the American Law Institute (ALI) approved R3RUE, a project led by its reporter professor Andrew Kull. Both the ALI and Professor Kull have reason to be proud of their ambitious 10-year effort to synthesise a wide and unruly field.

By its very nature, a Restatement isolates a legal field for 'restating' a narrowing activity that, as Macaulay observed in 1959, carries with it the potential to distort by removing context. The project recognized that restitution and contract often overlap where courts have purported to create a 'quasi contract' or 'restitution' solution to a problem involving a contract that failed. In an important subdivision of the Restatement, the project considers the use of restitution in such contract settings. ${ }^{2}$ It is here one finds a section addressing restitution for services provided when the provider and recipient disagree whether the contract requires them, ${ }^{3}$ restitution of profits from a breacher who has committed an 'opportunistic breach' ${ }^{, 4}$ and the extent to which a person in a losing contract can get restitution of benefits conferred on the breacher without regard to a potential loss on the bargain. ${ }^{5}$

This last is surely one of the most difficult problems addressed by the project and may well be most revealing of the project's underlying assumptions and ideas. The

\footnotetext{
${ }^{2}$ Restatement (Third) of Restitution \& Unjust Enrichment (St Paul, ALI, 2011) (hereinafter R3RUE) ch 4 $\S \S 31-39$ (entitled 'Restitution and Contract').

${ }^{3}$ R3RUE $§ 35$.

${ }^{4}$ R3RUE $\$ 39$.

${ }^{5} R 3 R U E \S 38$.
} 
traditional rule, as set out in Restatement (Second) of Contracts $\S 373$, permits the plaintiff who has made a losing contract to recover from the breacher the reasonable value of the benefits conferred on the breacher without regard to the bargain loss implicit in the original bargain. ${ }^{6}$ The rule was controversial when the Restatement was drafted, ${ }^{7}$ but the ALI elected then to follow the majority rule in the case law. While the case law had not changed appreciably in the interim, ${ }^{8} R 3 R U E$ changed this rule ${ }^{9}$ to one where the losing party will always absorb in a damages award some of the loss on the original bargain. Though there was scant support for change in the case law, the change was consistent with newly-dominant scholarly commentary supporting some form of reversal of the rule. ${ }^{10}$ But it remains to be seen whether the change is a sound one as a matter of policy and, perhaps more practically, whether courts, mired in context as they usually are, will recognize it. While its latest incarnation is in the Restatement (Third) of Restitution, the losing contract rule raises questions that lie near the core of contract law and offers an opportunity to consider the methodology and underlying assumptions we bring to thinking about contracts. ${ }^{11}$

The easiest way to dig into the question is through a simple problem. Suppose Dimwitted Contractor contracts to build Owner a house for the price of $\$ 150,000$. Whether desperate for work in the recession, overly optimistic about his own costs, or

\footnotetext{
${ }^{6}$ Restatement (Second) of Contracts (St Paul, ALI, 1981) § 373(1) and cmt a.

${ }^{7}$ See 56th ALI Proceedings (1979) 406-12.

${ }^{8}$ Recent cases are collected in G Palmer and L Kaplan, Law of Restitution (2011 Cum Supp) (Wolters Kluwer) $§ 4.4(a)$, n 7 a.

${ }^{9}$ The issue was settled in 2003.

${ }^{10}$ See authorities cited in R3RUE $§ 38$ Reporter's Note d.

${ }^{11}$ The Reporter has gathered much of the scholarly commentary on the rule in R3RUE $\S 38$ Reporter's Note

d. To the Reporter's list, one must add, at least, the excellent article supporting the traditional approach by B Gegan, 'In Defense Of Restitution: A Comment on Mather, Restitution as a Remedy for Breach of Contract: The Case Of The Partially Performing Seller' (1984) 57 Southern California Law Review 723.
} 
just plain stupid, Contractor has seriously underpriced the construction. The value of what the contractor has agreed to do and what other contractors would charge for the same job is $\$ 200,000$ and it will cost the contractor that much to do the work. Owner knows she drove a hard bargain and is getting a great deal (a $\$ 200,000$ job for $\$ 150,000$ or a gain of $\$ 50,000)$. Even better from owner's perspective, she has negotiated a payment schedule that requires her to pay half the price $(\$ 75,000)$ when the job is 80 per cent complete and the other half when it is completed. When Contractor has done precisely 80 per cent of work (at a cost of $\$ 160,000$ ), Owner refuses to pay anything at all and ejects him from the job, asserting a substantial breach by Contractor as the reason. This act, in fact, constitutes Owner's substantial breach of the contract and we can assume a court would so hold. How should we measure the contractor's recovery?

This question has puzzled courts and commentators for more than a century. Were we to award the contractor's 'expectation damages', we would put the contractor into the position he would have been in if the contract were fully performed. ${ }^{12}$ In an 80 per cent completed contract like this, it would mean we would award the amount the owner did not pay, $\$ 150,000$ minus the contractor's 'loss avoided' $(\$ 40,000)$, or $\$ 110,000^{13}$ for the $\$ 160,000$ worth of work completed. ${ }^{14}$ An 'expectation damages' award would preserve the integrity of the original bargain, since the contractor should be seen as having bargained at the outset to lose $\$ 50,000$ if he completed the entire job. One who asserted the sanctity and primacy of the contract that was negotiated would take this approach. ${ }^{15}$

\footnotetext{
${ }^{12}$ Restatement (Second) of Contracts $§ 344 \mathrm{cmt} \mathrm{b.}$

${ }^{13}$ Our contractor avoided $20 \%$ of the $\$ 200,000$ worth of work due to the owner's breach, so under the expectation measure he should get the contract price, $\$ 150,000$ minus $(0.2 \times \$ 200,000)=\$ 110,000$ as a final payment for the work done.

14 eg, Restatement (Second) Contracts § 347; compare Restatement (Second) Contracts § 373.

15 This 'full expectation' treatment was advocated in H Mather, 'Restitution as a Remedy for Breach of Contract: The Case of the Partially Performing Seller' (1982) 92 Yale Law Journal 14.
} 
An alternative way of looking at it is to consider the owner's substantial breach to be the equivalent of the end of the bargain. Why, one might ask, should a breacher be effectively entitled to her profit when she induced the contractor's work by making her own promise but then did not then earn her own profit by fully performing the contract? Promises were, of course, exchanged. But in a contract setting, the promisor did not make a promise 'to' herself but made it 'to' another person in the context of a bargain. Each promise was conditional on, and made in anticipation of-in reliance on-actually receiving what the other side promised. Indeed, a fair reading in nearly any case is that the parties were bargaining for the performances the promises represented, not simply for the substitutional relief value that a later trier of fact might place on the promises; an award of expectation damages is but one of many ways to measure that loss of the anticipated performance. ${ }^{16}$ On this view, by destroying the reciprocal context in which the promise was made, a substantial breach has destroyed the only reason to use the bargain as a point of reference for damages. Having removed the implications of the bargain, this view continues, what remains to be done is to assess damages for the owner's breach. Since the expectation measure is itself but an approximation of real damages, there is no essential reason to use expectation as a limit on what the loser might obtain. And since the winner actually received some of the performance contemplated, the reasonable value of which would be easy for the winner to estimate and factor in at the making of the bargain, ${ }^{17}$ there is little danger of throwing onto the winner an unknowable risk that might have produced the loser's bad bargain if that 'reasonable value' were used. Under those circumstances, awarding the value of the work done is an acceptable solution.

\footnotetext{
${ }^{16}$ Professor Corbin saw the remedy not as a remedy for unjust enrichment but rather as a simple alternative way to measure injury. See A Corbin, Corbin On Contracts, vol 5 (St Paul, West Publishing, 1950) $§ 1106$.

${ }^{17}$ Certainly it would be easier for the winner to estimate this figure than it is to estimate the consequential damages that might result from the winner's breaching the contract.
} 
This 'reasonable value' approach (however we might articulate its theory) would give the contractor $\$ 160,000$, effectively erasing the implications of the bad bargain he made. At the same time, it does not preserve the benefit of the bargain for a party who, after all, did not earn that benefit through full performance. This approach, adopted by most courts in the twentieth century but questioned by many commentators, was, after strong debate, ${ }^{18}$ enshrined in the Restatement (Second) of Contracts. ${ }^{19}$ There are also two solutions that might be regarded as compromises, somewhere between 'expectation damages' and 'reasonable value'. One approach would award 'reasonable value' but would limit the owner's liability to the total price she agreed to-here, $\$ 150,000 .^{20}$

$R 3 R U E$ takes still a different mid-way approach, creating the 'contract rate rule', an approach recognized by a few nineteenth-century courts (and, in sales of goods cases, by Article 2 of the Uniform Commercial Code). ${ }^{21}$ In the simple example above, R3RUE would provide that plaintiff contractor should be paid at the contract rate. Here, that would give the contractor 80 per cent of the contract price $-0.8 \times \$ 150,000$, or

\footnotetext{
${ }^{18}$ ALI Proceedings (n 7).

${ }^{19}$ Restatement (Second) Contracts $\S 373$. The new Restatement of Restitution does preserve in $\S 37$ one variation of the Restatement of Contracts solution: If a buyer of goods or services has prepaid on a losing contract and the supplier has failed to deliver any performance, the buyer can get his money back without any deduction for having made a bad bargain. This result follows Bush v Canfield, 2 Conn 485 (CT 1818), a well-known case reaching that result. R3RUE preserves this particular outcome by introducing 'rescission', a remedy that simply reverses the transaction (and therefore gives the buyer restitution of the down payment without any deduction for loss on the bargain). Rescission is not available once values need to be established for a part performance-where the court cannot 'unscramble the egg'. A Kull, 'Rescission and Restitution' (2006) 61 Business Lawyer 569, 577. R3RUE's narrow rescission remedy would thus not be available in the example discussed in the text.

${ }^{20}$ See Johnson v Bovee, 574 P2d 513 (Colo Ct App 1978); Wuchter v Fitzgerald, 163 P 819 (OR 1917).

${ }^{21}$ Uniform Commercial Code § 2-607(1). A 'contract rate' approach is also sometimes used in employment contract cases; see G Palmer, Law of Restitution, vol 1, § 4.4 (Wolters Kluwer) 394.
} 
$\$ 120,000 .^{22}$ This preserves some of the contract's profit/loss allocation, but only that portion that 'accrued' during the actual performance of the contract; the owner earns her pro rata profit up to the time she breaches but not afterward. This solution was found in a couple of well-known nineteenth-century cases that were not widely followed in the twentieth century. ${ }^{23}$

In rejecting the conventional judicial solution to this problem, R3RUE bends to a chorus of modern academic commentators that viewed the 'reasonable value' solution as 'unjustly enriching' the contractor ${ }^{24}$ (mostly because it ignored the contractor's loss on the bargain) and rejects the views of earlier contracts scholars such as Corbin and Fuller and restitution scholar Palmer. It also rejects the 'expectation damages' solution, one that preserves the full expectancy of both breacher and non-breacher and is, perhaps, most logically in accord with what one might view as the parties' initial bargain.

Perhaps because it is a compromise, there is something intuitively appealing about the Restatement's 'contract rate' solution to the problem. After all, these parties did make a bargain and, assuming no invalidity on account of duress, mistake, or unconscionability, it is perhaps safe to assume that the values they may have placed on their commitments ought to survive anyone's breach. On the other hand, allowing the breacher to preserve the whole benefit of that bargain with little or no performance seems wrong. The contractor bargained for an actual, full performance, not a partial one; and he certainly wasn't simply making a bet. ${ }^{25}$

\footnotetext{
${ }^{22} R 3 R U E \S 38(2)(\mathrm{b})$.

${ }^{23}$ The main cases supporting illustrations in the Restatement's new rule include Kehoe v Rutherford, 27 A

912 (NJ 1893), Doolittle \& Chamberlain v McCullough, 12 Ohio St 369 (OH 1861), and Noyes v Pugin, 27

P 548 (WA 1891).

${ }^{24} R 3 R U E \S 38 \mathrm{cmt} \mathrm{d}$.

${ }^{25}$ See Corbin, Corbin On Contracts (n 16).
} 
That the new Restatement has rejected what seemed to be the reasonably settled majority view of the courts during the bulk of the twentieth century and replaced it with a very innovative, but not widely followed compromise position reflected in a few nineteenth-century cases is itself interesting. In the process, the 'situation sense', ${ }^{26}$ or context, $^{27}$ that twentieth-century courts may have brought to the problem has been displaced by judicial visions of contract law from an earlier era and by academic commentary of a century later. If the Restatement's solution has replaced one reached within rich factual contexts with one reached through detached theory, it is one that Macaulay has taught us could be suspect.

\section{Instrumental Analyses of the Problem}

This Section considers the losing contract problem in the context of empirical research into the behaviour of those who make and perform contracts. It does so by taking findings from an area of that research and inserting them into an instrumental analysis of the kind used to support the new losing contract rule formulated by the Restatement. Instrumental analysis in legal discourse is ubiquitous; it may be no coincidence that it has also proven to be extraordinarily malleable. As one might expect, an instrumental analysis that is begun with different premises or assumptions is likely to produce different outcomes.

\footnotetext{
${ }^{26}$ See K Llewellyn, The Common Law Tradition: Deciding Appeals (Boston, Little, Brown \& Co, 1960) $121-57$.

27 S Macaulay, 'Restitution in Context' (1959) 107 University of Pennsylvania Law Review 1133.
} 


\section{A. Instrumental Analysis and Assumed Party Behaviour}

At the core of the instrumental analysis condemning the old 'reasonable value rule' is a prediction about how contractors will behave under it. The instrumental analysis starts with assumed contractor behaviour, proceeds to the conclusion that the traditional rule is 'inefficient' and that, in turn, leads to a normative conclusion that the rule ought to be changed. We consider here the validity of that initial behavioural prediction within the wider context of empirical work of the kind pioneered by Macaulay together with newer experimental work that extends Macaulay’s empirical work.

In the context of our hypothetical problem, the instrumental analysis begins with the premise that our dimwitted Contractor, stuck in the midst of performing a losing contract, will react to his situation by responding solely to economic incentives and behave strategically by finding a way to induce the other side to breach. ${ }^{28} \mathrm{He}$ will do this under the current rules allowing restitution for breach because he will then recover more in the ensuing litigation: the 'reasonable value' of his performance rather than a recovery limited in some way by the breacher's less generous promise. What is worse, the 'reasonable value rule', it is said, encourages this kind of strategic behaviour and is inefficient because the parties will expend resources trying to enhance their litigation position rather than finding an appropriate contract modification. ${ }^{29}$ And since, it is said, the parties would not choose such a rule at the outset, ${ }^{30}$ setting the 'reasonable value rule' as a default rule would be inefficient because it would require the parties to negotiate a change in this inefficient rule, or be stuck with it, in their contracts.

\footnotetext{
${ }^{28}$ A Kull, 'Restitution as a Remedy for Breach of Contract' (1994) 67 Southern California Law Review 1465, 1472; M Gergen, 'Restitution and Contract: Comments on the Third Restatement' (2005) 13 Restitution Law Review 224, 237; compare D Laycock, Modern American Remedies, 4th edn (New York, Aspen Publishing, 2010) 693 fn 4.

${ }^{29}$ Kull, 'Restitution as a Remedy' (n 28) 1472.

30 ibid 1517.
} 
This abstract analysis is demonstrably malleable. For example, a similar kind of abstract 'efficiency' analysis that could support the opposite normative conclusion (that is, support the current majority rule) would simply denominate the losing contract rule a 'penalty default rule.' To illustrate, let us assume that the parties would respond predictably to strict economic incentives and, therefore, would predictably engage in strategic behaviour. The prescient parties to the contract would know that undesirable remedial incentives would develop during performance. This knowledge would encourage them to negotiate around this 'bad' rule at the outset and thereby avoid the undesirable (and inefficient) judicial intervention about remedy at the litigation stage of their relationship. ${ }^{31}$ A party-crafted solution, the argument would go, is inevitably superior to (that is, more efficient than) any general rule developed by the legal system. The parties' knowledge of and desire to avoid the government-imposed default rule would encourage them to develop a more efficient, individualized solution.

Because this kind of instrumental analysis is so easily manipulated, it is ultimately indeterminate as a normative matter. However, even if it were less indeterminate, abstract instrumental analysis begs the question whether it can offer much guidance at all in this complex setting. Unlike those provided by, say, a tax rule (for example, charitable contributions are deductible), the incentives imagined here are required to operate within highly-variable, unique, rich relational contexts where even if the incentives were accurately imagined, they compete with other incentives operating on the parties, such as the contractor's concern for business reputation, the availability of other options for the owner, the delay occasioned by a breakdown in the contract and so on. ${ }^{32}$ Moreover, the analysis ignores the substantial transaction costs of the litigation alternative, as well as the potential for consequential damages, and assumes that the expectancy will be 'the same'

\footnotetext{
${ }^{31}$ See generally I Ayres and R Gertner, 'Filling Gaps in Incomplete Contracts: An Economic Theory of Default Rules' (1989) 99 Yale Law Journal 87.

${ }^{32}$ Compare K Llewellyn, 'What Price Contract' (1931) 40 Yale Law Journal 704; S Macaulay, 'The Use and Non-Use of Contracts in the Manufacturing Industry' (1963) 9 Practical Lawyer 14.
} 
whether it is delivered through a profitable performance by the losing contractor or through contract damages awarded to the winning owner in the win or lose litigation. Such assumptions are, of course, extremely unrealistic. The relational forces one can expect to operate in this context, and the transaction costs of litigation (not to mention the other unrecoverable losses implicated in a failed contract) may well dwarf other values that might be in play and, if taken into account, suggest that, whatever the rule, it may have little effect on the behaviour of the parties within the troubled contract. ${ }^{33}$ Except where the bargain is very large and extremely unbalanced in the winner's favour, the 'winner' will likely be economically better off with (and motivated towards) a successful negotiation regardless of the rule.

But even if one downplays the substantial noise produced by the complicated set of forces operating on the parties when a relational contract is in trouble, the incentives produced within that context by the current losing contract rule might well generate collaborative rather than self-interested responses. If the incentives produced by the losing contract rule work differently than imagined, the acontextual analysis that proceeds from it (whatever it may be worth) may be faulty.

At the core of the 'noise-free' normative economic analysis described is the implicit empirical assertion that people actually behave in the way the abstract model assumes. An implication is that reform through a different (more efficient) rule will prompt people to behave differently (and, one must assume, more efficiently). Someone following Macaulay and searching for real-world context might well ask: 'Is that really how someone performing a losing contract will behave?' If initial assumptions about human behaviour control the ultimate normative prescription, and if the goal is actually

\footnotetext{
${ }^{33}$ R Woodward and W Woodward, 'Exemptions as an Incentive to Voluntary Bankruptcy: An Empirical Study' (1983) 57 American Bankruptcy Law Journal 53 (finding that the predicted incentive effects on the rate of consumer bankruptcy filings from high and low state exemption provisions were not sustained by the data).
} 
achieving efficient results in the real world, then we ought to get more valid prescriptions from an analysis that is better grounded in actual human behaviour. Actual human behaviour is, obviously, responsive to context; it will respond to whatever incentives the losing contract rule actually provides within the context of relatively long-term, relational contracts. Those contracts tend to be personal, unique and complex, on the other end of the contractual spectrum from swaps and other contracts that are only about shifting risks.

While one must be extremely sceptical that any rule will have real incentive effects on the parties within this context, a slight variation in initial assumptions tends to press in favour of the 'reasonable value rule'. Consider a different contractor stuck in the same losing contract, but this time with just a little more context added in. Once this contractor discovered he was operating at a loss, he might approach the owner to begin a negotiation. One could imagine many reasons for what has evolved into a losing contract for the contractor-post-contract component price increases, weather problems, labour problems - that many would consider good reasons to open a negotiation aimed a price adjustment (advantage-taking at the formation stage must be eliminated since this modeling assumes that both parties are fully knowledgeable, have equal bargaining power and so on). Many (if not most) owners, when faced with such a contractor, would in a real construction contract find it in their best interests to reach an accommodation. No owner wants to live with a construction job delivered by an unhappy or angry contractor-there are too many undetectable ways for a contractor to skimp on quality or otherwise frustrate the value of its performance. Put differently, if trust between the parties to a relational contract is broken, even if the owner gets some kind of performance, he might well not receive a reliable product.

If one imagined that the contractor's first move would be to approach the owner for a concession, rather than cutting corners, simply walking away, or strategically inducing the owner into breaching, then perhaps the situation would call for a rule that would encourage a collaborative adjustment of the losing contract in order to avoid its collapse. This would, at minimum, avoid the deadweight costs of non-consensual, 
governmental dispute resolution. ${ }^{34}$ If one begins a rational actor analysis in a slightly different place, one might well come to an entirely different normative outcome.

We can test the available ways to address the losing contract problem by considering the likelihood of a consensual contract price modification when initiated by the losing contractor in the midst of performance of the contract in order to avoid a breakdown of the contract. Assuming that rules could produce some effect on the behaviour of the parties in this context, what incentive effects might be imagined from the current rules embodied in the Restatement (Second) of Contracts? Under those rules, the winner-owner obtains the gain on the bargain if the loser-contractor has materially breached $^{35}$ but loses that gain (and the contractor avoids that loss) if the winner-owner has materially breached. ${ }^{36}$ These rules may actually have the effect of motivating an adjustment in order to avoid collapse of the contract, once the loser opens negotiations. These traditional rules create a downside for each of the parties should the litigation go the wrong way for them, a corresponding upside if the litigation goes right, and substantial uncertainty about which it will eventually be. Because of the uncertainty implicit in these rules, both parties will be motivated to reach a modification in order to avoid a breakdown of the contract and the hard-to-consensually-resolve dispute that will

\footnotetext{
${ }^{34}$ See, eg I Macneil, 'Efficient Breach of Contract: Circles in the Sky' (1982) 68 Virginia Law Review 947. Professor Macneil argued that an individualistic, non-relational perspective produces 'inefficient' outcomes. In critiquing simple law and economics reasoning epitomised by efficient breach analysis, he wrote: 'The bias against cooperation demonstrated by the simple-efficient-breach theory should surprise no one familiar with the neoclassical model. Such a bias is not limited to this particular fallacy, but is one towards which the neoclassical model inevitably and always tends. That model postulates individuals acting as if the relations in which those individuals exist have no effect on their behavior. Cooperative behavior postulates relations. A model assuming away relations slips with the greatest of ease at any stage into favoring uncooperative and —ironically enough— highly inefficient human behavior.' ibid 969.

${ }^{35}$ Restatement (Second) Contracts $\S 347,349$.

${ }^{36}$ ibid $\S 373$.
} 
follow. And while both parties may have some reason to strategize in this setting, this motivation pales in comparison with their motivation to keep the contract going and avoid the uncertainties of litigation.

Again, recognizing that whatever incentive effects the rules might produce are likely to be overwhelmed by the 'noise' of the situation, the full expectancy rule as embodied in Restatement (Second) of Contracts $\S \S 347-48$ (where the gain or loss on the bargain was fully allocated at contract formation and did not vary at all depending on who breached) would seem to produce less reason to consensually modify the ongoing contract. Under this rule, the winner 'wins' her expectation regardless of who breached or where in the performance the contract broke down. In this hypothetically 'noise-free' environment, the 'winner' has little downside to holding out - she gets the same expectancy, either through actual performance if the loser sticks it out, through contract damages if the winner wins on the breach question, and through a deduction of that same expectation amount from the loser's damages if she loses on the breach question. If the contract breaks down and a dispute ensues, it will be relatively easy (less costly) to resolve since nothing would depend on who breached first. This is consistent with the view that the contract defines all obligations at the point of contract formation and that post-formation flexibility is either beside the point or undesirable. Professor Henry Mather advanced this view based not on economic analysis (which he viewed as inconclusive) but on a libertarian idea that the law should strive towards minimal coercion and that liability should follow only from consent. ${ }^{37}$

$R 3 R U E$ 's new 'contract rate rule', a hybrid of the two extremes, would at first blush seem to lie somewhere between the two in its tendency to promote a contract adjustment, since it ultimately produces a sliding scale of economic incentive. Like the 'reasonable value rule', its operation, too, depends on who is ultimately identified as the 'first material breacher'. If the loser is the breacher, the economic result is the same as it

\footnotetext{
${ }^{37}$ Mather, 'Restitution as a Remedy' (n 15) 30.
} 
is under the Restatement of Contracts: reliance damages minus the victim-winner's full expectation under the contract. ${ }^{38}$ But if the winner is the breacher, the rule is more complicated than the traditional rule. Under the 'contract rate rule', the winner would secure a fraction of her profit (that part represented by the percentage of the contract that is complete) if she were found to be the breacher. ${ }^{39}$ So, while material breach continues to be central to triggering that rule, the stakes that ride on the question become smaller the further along the contract proceeds in performance.

If the contract is 90 per cent complete at the time it breaks down, for example, the winner will recover 90 per cent of her expectancy if she is found to be the breacher and 100 per cent if the loser has breached. This gives the winning owner less economic reason to agree to a price adjustment the further along in performance the contract is. The tendency of the new R3RUE rule to motivate consensual modification depends on the performance progress of each contract under consideration.

The 'reasonable value rule' also produces a sliding scale of economic motivation but in the opposite direction: as the losing contract progresses, the gap between the winner's expectation recovery and the loser's 'reasonable value' recovery widens. If the size of the gap motivates action, then there is more motivation as the contract progresses towards full completion than there is at the start of the contract. This could supply more motivation for strategic action, ${ }^{40}$ or, as developed in the text, more motivation to adjust the contract rather than face the uncertainties of a breakdown followed by a dispute resolution process. Which incentives a given rule actually supplies to real people in these settings is ultimately an empirical question that, given the 'noise' of the situation, is not likely to be resolvable.

\footnotetext{
${ }^{38}$ Restatement (Second) Contracts § 349; R3RUE § 38(2)(a).

${ }^{39} R 3 R U E \S 38(2)$ (b). The recovery is to be one 'not exceeding the price of such performance as determined by reference to the parties' agreement' (emphasis added). See also R3RUE $\S 38(2)(\mathrm{b}) \mathrm{cmt} \mathrm{c}$.
} 
Relational contracts gather inertia as performance advances and the parties sink tangible and intangible investments into its performance. If a rule can add anything at all to the pre-existing incentives of the parties in these complicated settings, then arguably a rule that increased incentives to keep the contract together as it gathers inertia would seem preferable to one that did the opposite.

$R 3 R U E$ recognizes that it may not be possible to apply the 'contract rate rule' in all cases and, importantly, what the rule should be if that is not possible. Comment $\mathrm{d}$ provides, in part:

By capping the damage calculation at the contract rate (where it can be determined), $\S$ 38(2) prevents these plaintiffs as well from electing performance-based damages as a means of escape from an unfavorable bargain.

This, of course, contributes substantial uncertainty to the rule's application.

The new approach has undoubtedly added complexity to the analysis (in a real dispute, would the parties ever fail to contest what portion of the total work was actually completed?); if projected uncertainty in dispute resolution will motivate a contract adjustment to keep the contract together, the $R 3 R U E$ approach might, ironically, supply the best motivation of all the rules.

It should be obvious that a rational actor analysis is highly indeterminate in this setting, not only because of the complexity of the relational contexts in which the parties will likely find themselves but also because the rational actor analysis itself depends on initial speculation about how people will actually behave in a given environment. Rational actor analysis of the kind described here typically assumes a rigorously self-

\footnotetext{
${ }^{40}$ See Kull, 'Rescission and Restitution' (n 19) 1472.
} 
interested actor on whom economic incentives alone operate in a context-free environment. As suggested above, one can imagine a rational actor behaving in different ways in response to economic stimuli and, of course, the behaviour selected can control the ensuing analysis. The alternate rational actor just imagined responds to economic stimulation with co-operation rather than entirely self-interested strategizing.

\section{B. Adding Empirical Observations to an Instrumental Analysis}

Is there any support beyond pure intuition for recasting the rational actor in the way just described? Following Macaulay, one might ask: 'What would contracting parties actually do in this relational contract environment?'

We might be helped in this inquiry by behavioural economics, the discipline within the broad empirical tradition that Macaulay championed over 50 years ago that seeks answers to just these sorts of behavioural questions. Many studies conducted by these scholars have established that human beings do not respond to economic stimuli in the way an exclusive focus on self-interest (indeterminate as that focus may be) might suggest. ${ }^{41}$

The older behavioural scholarship has attacked traditional economic analysis in its most basic assumptions. Shown either to be wrong or to be sufficiently inaccurate as to

\footnotetext{
${ }^{41}$ It would be great overstatement to suggest that the new research has done much to dampen the continued dogged outpouring of scholarship employing (now) old-fashioned Chicago School economic analysis. The persistence of traditional law and economics analysis might, ironically, be a function of the self-interest of those who practice it. See J Hanson and D Yosifon, 'The Situation: An Introduction to the Situational Character, Critical Realism, Power Economics, and Deep Capture' (2003) 152 University of Pennsylvania Law Review 129.
} 
distort analysis are the assumptions that those making contracts can take into account enough factors to maximize their own utility, that they are realistic in their forecasts of the future, or that they are capable of using the available data to make decisions. ${ }^{42}$ While the empirical data supporting these attacks come largely from experimental studies of human behaviour, field observations made much earlier by Macaulay and others about the behaviour of those in business that use contracts in their work tend to corroborate more recent work. ${ }^{43}$

This scholarship has been remarkably provocative, but, like Macaulay's, has not generally produced a positive normative agenda: if analysis begins with the proposition that people are not very rational, are not good planners, or are careless with their communications and commitments, it is hard to see what sorts of rules one might develop to serve them better. Put more specifically, the older researchers could convince us that our losing contractor might be 'irrational' (in a narrow rational actor sense), but could give little guidance into how (other than 'irrationally', in that same narrow sense) he might behave - or what might influence that behaviour-when embroiled in a contract that was losing money. The newer work may have more promise.

By designing experiments to test specific assumptions and rules in the law of contracts, the newer empirical researchers have gone beyond simply challenging economic 'rationality' itself to focusing on how real people actually behave when faced with contract problems. That research has identified a strong reciprocity norm ${ }^{44}$ affecting the behaviour of those who deal with one another, a norm whose effect is largely missing

\footnotetext{
${ }^{42}$ A succinct summary of the then-extant literature is in M Eisenberg, 'Why There is No Law of Relational Contracts' (2000) 94 Northwestern University Law Review 405. See also A White, 'Behavior and Contract' (2009) 27 Minnesota Journal of Law and Inequality 135.

${ }^{43}$ A recent contribution is C Hill, 'Bargaining in the Shadow of the Lawsuit: A Social Norms Theory of Incomplete Contracts' (2009) 34 Delaware Journal of Corporate Law 191.

${ }^{44}$ In the context of public choice, see, generally D Kahan, 'The Logic of Reciprocity: Trust, Collective Action, and Law' (2003) 102 Michigan Law Review 71.
} 
from the rational actor analysis so pervasive in the literature. ${ }^{45}$ Professor Dan Kahan has defined this in the context of public choice this way:

The reciprocity theory holds that individuals in collective action settings behave not like rational wealth maximizers but rather like moral and emotional reciprocators. When they perceive that other individuals are voluntarily contributing to public goods, most individuals are moved by honor, generosity, and like dispositions to do the same. When, in contrast, they perceive that others are shirking or otherwise taking advantage of them, individuals are moved by resentment and pride to withhold their own contributions and even to retaliate if possible. The reciprocity theory implies that because individuals behave in this fashion, the most effective means to promote cooperative behavior in collective action settings is to promote trust - the shared belief that others can in fact be counted on to contribute their fair share to public goods, whether or not doing so is in their material self-interest. Indeed, the reciprocity theory warns that incentives can often backfire by implying that most individuals are not inclined to contribute to collective goods voluntarily.

This observation is closely related to Robert Axelrod's experiments showing that a 'tit for tat' strategy that began with co-operation was the most successful and 'profitable' strategy for addressing the prisoner's dilemma over the long run. The reciprocity norm, at its core, is relational and co-operative rather than individualist and self-interested. ${ }^{46}$ One can also see it as corroborating many of Macaulay's and Macneil's observations.

In one very provocative recent study, ${ }^{47}$ researchers examined how the reciprocity norm operated in the context of breach of contract. Their focus was on whether real persons care what the reason for a breach is and, if they do, how much they care and why. The researchers demonstrated that if the breach were the result of the breacher

\footnotetext{
${ }^{45}$ D Kahan, 'Signaling or Reciprocating: A Response to Eric Posner's Law and Social Norms' (2002) 36

University of Richmond Law Review 367.

${ }^{46}$ See, generally R Axelrod, The Evolution of Cooperation (New York, Basic Books, 1984).

${ }^{47}$ D Hoffman and T Wilkinson-Ryan, 'Breach is for Suckers' (2010) 63 Vanderbilt Law Review 1003.
} 
deliberately taking advantage of a better opportunity, ${ }^{48}$ the subjects would award higher damages than they would in a case where the breach were for reasons outside the breacher's control. These findings are corroborated by others observing the behaviour of contracting parties in the field.

The researchers inferred from this behaviour that real people who had brought the reciprocity norm to contracting feel 'suckered', and seek to retaliate when that norm is violated by their contracting partner. The authors concede that the findings, while statistically significant, are preliminary. ${ }^{49}$ But the implications of the effects of an empirically observed reciprocity norm on contracting behaviour should be deeply disturbing to theorists who assume that no such value, dynamic, or motivation exists. For example, this empirically observed behaviour has the potential to undercut a core assumption of much economic analysis about contracts, that contracting parties are indifferent to whether they receive actual performance or expectation damages. ${ }^{50}$ This assumption is behind the largely discredited ${ }^{51}$ - but still widely discussed ${ }^{52}$ - efficient breach paradigm and is a starting point for scores of articles that analyze contract damage rules through an instrumentalist analysis.

These newer findings may also have the potential for anchoring a less destructive, more positive normative effort at shaping rules to match the behaviour of those subject to them. Our hypothetical case here may be an example: if one took seriously the presence of a reciprocity norm within a relational contract, one might have empirical support for

\footnotetext{
${ }^{48}$ This, of course, would be a so-called 'efficient breach'.

${ }^{49}$ Hoffman and Wilkinson-Ryan, 'Breach is for Suckers' (n 47) 1036.

${ }^{50}$ Oliver Wendell Homes is usually credited with promulgating the idea. OW Holmes, Jr, The Common Law (Boston, Little, Brown \& Co, 1881). This idea has been under siege for many years but until recently the attackers have not had empirical data to back up their challenges.

${ }^{51}$ The best of the critiques remains Macneil's; Macneil, 'Efficient Breach of Contract' (n 34).

${ }^{52}$ See, eg M Jiminez, 'The Value of a Promise: A Utilitarian Approach to Contract Law Remedies' (2008) 56 UCLA Law Review 59.
} 
the proposition that our loser, when faced with performing a losing contract, would actually begin with an effort to negotiate, rather than with behaviour that was less relational and more self-centered and strategic. It might also support the proposition that, rather than rebuff such an encounter, the winner might well — and should - entertain it. Indeed, Axelrod's findings on player strategies for addressing the iterated prisoner's dilemma ${ }^{53}$ suggests that this contractor's strategy-initial co-operation rather than 'defection' in addressing the pricing within the contact - and the owner's co-operation, is also the most effective in the long run. Researchers-even those working at the hypothetical level without rich factual context - who began with this different set of initial moves could understand the instrumental dynamics differently and, perhaps, begin a normative analysis that resonates better with observed contracting behaviour.

But while different initial assumptions might lead to different normative prescriptions, a main point of the foregoing discussion was to suggest that any prescriptive instrumental analysis of the incentives that might operate within a relational contract is fraught with problems. In the relational contract context particularly, it is very unlikely that instrumental analysis (whatever its initial assumptions about human behaviour) can point to any reliable policy prescriptions, even if one agreed that the goal was simply to produce an 'efficient' rule.

Where does this inconclusiveness lead one as a normative matter? It might well suggest that the wisest course for R3RUE would have been to defer (as did the Contracts Restatement) to the wisdom of the courts, situated as they have been in the thick context of these problems. Certainly the dominant case law and an accepted view of the goals of a 'restatement' project ${ }^{54}$ could have justified leaving the Restatement of Contracts rule undisturbed.

\footnotetext{
${ }^{53}$ Axelrod, The Evolution of Cooperation (n 46).

${ }^{54}$ See Shapo, 'In Search of the Law' (n 1) 634-35.
} 


\section{The Ideological Context for the New Rule}

While the reciprocity norm has enormous implications for contract theory, the complexity of a relational contract context makes an instrumental analysis that emphasizes the reciprocity norm subject to the same criticism as an instrumental analysis that emphasizes purely self-interested behaviour. The result of such inconclusiveness would suggest deference to the status quo in most instances.

In this Section we consider the losing contract problem from a different perspective. While assumptions about human behaviour can animate an instrumental analysis that can buttress one's normative views about the losing contract rule, one's views about the nature of contract law can also determine how one conceives of the problem and its solution. Here, again, reciprocity has powerful explanatory potential: it may help explain what may have happened between the restatement of the traditional rule in the Restatement (Second) of Contracts in 1981 and the 'restatement' of the new rule in $R 3 R U E$ in $2011 .^{55}$

Embedded in $R 3 R U E$ 's approach to the losing contract problem lies an adherence to a particular theory of contract law that leads to its sharp separation from the conception of restitution that animates the new Restatement. The two systems are conceived of as entirely separate and contract law is dominant. ${ }^{56}$

\footnotetext{
${ }^{55}$ Some of what follows owes its genesis to the discussion of contract in M Sandel, Justice: What's the Right Thing to Do? (New York, Farrar, Straus, and Giroux, 2009) and the lectures that preceded the book.

${ }^{56}$ This same 'system separation' animated attacks on the tort of interference with contract which in many respects, it was contended, was inconsistent with the teaching of 'efficient breach'. Ultimately those attacks, too, conceived of contract law as separate and 'dominant', but this time over tort law. The attacks are
} 
R3RUE $§ 2$ Comment c makes this clear:

Contract is superior to restitution as a means of regulating voluntary transfers because it eliminates, or minimizes, the fundamental difficulty of valuation. Considerations of both justice and efficiency require that private transfers be made pursuant to contract whenever reasonably possible and that the parties' own definition of their respective obligations-assuming the validity of their agreement by all pertinent tests-take precedence over the obligations that the law would impose in the absence of agreement. Restitution is accordingly subordinate to contract as an organizing principle of private relationships, and the terms of an enforceable agreement normally displace any claim of unjust enrichment within their reach. ${ }^{57}$

This means that if a situation involves an enforceable contract, then it must have a solution grounded in contract, and only in contract.

That particular conception of 'contract law' that supplies a 'contract' answer to any problem involving an enforceable contract is itself a particular one that sees the field as coextensive with 'promise ${ }^{, 58}$ or, alternatively, 'consent' ${ }^{59}$ Once the problem is defined as having an enforceable contractual underpinning, then liability should not go beyond the 'promise' made by the breacher or beyond her consent to liability as represented by the

described and discussed in W Woodward, Jr, 'Contractarians, Community, and the Tort of Interference with Contract' (1996) 80 Minnesota Law Review 1103. The 'citadel' of privity - that is, the dominance of contract - also lies behind the peculiar development of products liability law in the United States. See generally W Prosser, 'Assault Upon the Citadel' (1960) 69 Yale Law Journal 1099.

${ }^{57}$ See, generally C Saiman, 'Restating Restitution: A Case of Contemporary Common Law Conceptualism' (2007) 52 Villanova Law Review 487. See also M Gergen, 'Restitution as a Bridge over Troubled Contractual Waters' (2002) 71 Fordham Law Review 709, 739.

${ }^{58}$ C Fried, Contract as Promise: A Theory of Contractual Obligation (Cambridge, Harvard University Press, 1981).

${ }^{59}$ See R Barnett, 'A Consent Theory of Contract' (1986) 86 Columbia Law Review 269; compare Mather, 'Restitution as a Remedy' (n 15). 
promise. Harm to the plaintiff, if it goes beyond the promisor's commitment, might be important but is subordinate to the higher principle of limiting the promisor's liability to the value of the promise. In this way, a promise may serve primarily as a limit to the individual promisor's liability rather than as a reciprocal commitment to one's contracting partner. And expectation damages, being ultimately based on the value of the promise (rather than harm done through breach), becomes a cardinal component in this vision. In the losing contract setting, giving the loser-plaintiff a remedy that exceeds the value one calculates based on the breacher's promise would, it is said, 'unjustly enrich' the plaintiff, presumably by giving the loser plaintiff more than he bargained for, ${ }^{60}$ or exposing the promisor to more liability than she assumed. ${ }^{61}$ This view of contract accords great respect to personal autonomy and freedom, both to make contracts and, importantly in this context, from liability not voluntarily assumed. It tends to regard contract almost solely as a mechanism to shift risk rather than as a mechanism to shift risk and accomplish something through joint effort. Reciprocity, and the context that reciprocity gives to the act of making a commitment, has relatively little to do with it.

But there is, and probably always has been, a competing normative vision of the institution of contract, one based on the relational bond formed in many contracts, empirically observed by Macaulay and scores of others. ${ }^{62}$ In this view, once a contract is made, the contracting parties owe one another 'more' than the quantifiable measure of their respective promises. One can express that 'more' in a number of ways: the trust

\footnotetext{
${ }^{60}$ R3RUE, $\S 38 \mathrm{cmt}$ d.

${ }^{61}$ See generally Mather, 'Restitution as a Remedy' (n 15).

${ }^{62}$ This vision obviously has no application to bets, derivatives and other kinds of contracts where there is no actual performance contemplated by either side (other than the payoff). If one begins with this kind of contract as a paradigm, one will naturally develop a promissory vision of the institution. Compare Kull, 'Restitution as a Remedy' (n 28) 1484, quoted below in text accompanying n 74. While no-one would begin with bets as their touchstone for thinking about contracts, it is likely as an empirical matter that the vision one has of what 'typical' contracts are (lawyered, large transactions; consumer transactions; small-town,
} 
formed in the relationship, ${ }^{63}$ the sense of mutual reliance the contract represents, 'organic solidarity' ${ }^{64}$ 'morality', ${ }^{65}$ or (in the language of contemporary researchers) the obligation inferred from the 'reciprocity norm'. The importance of reciprocity in contracting has been described by philosophers ${ }^{66}$ and, as briefly developed above, has been identified empirically in contemporary studies of co-operative and contract behaviour. ${ }^{67}$

By definition, reciprocity adds to the act of promising the context in which each individual promise is made; the norm tends towards a 'compensatory' rather than a 'promissory' view of contract remedies, one that would seek to compensate for harm done to the promissee unless competing policies suggested limitations. Expectation damages, in this view, serve not as a bulwark against expanded promisor liability and essential to one's vision of the institution of contract, but as an efficient surrogate for compensating for the harm that one's breach causes another, one that encourages business and credit as well. This was, of course, a theory advanced by Fuller and Perdue in their famous 1936 article. $^{68}$

These different views of the rationale for the expectation measure of damages in turn can lead to a difference in one's view of the importance of the original bargain once it has been broken. If one's promise serves also as a core principle of limited liability,

informal business transactions; etc) has a lot to do with one's vision of the institution itself.

${ }^{63}$ See, generally O Williamson, 'Transaction Cost Economics: The Governance of Contractual Relations' (1979) 22 Journal of Law and Economics 233.

${ }^{64}$ The term is, of course, Ian Macneil's. See generally R Gordon, 'Macaulay, Macneil, and the Discovery of Solidarity and Power in Contract Law' (1985) 1985 Wisconsin Law Review 565, 568-70.

${ }^{65}$ See R Hyland, 'Pacta Sunt Servanda: A Meditation' (1994) 34 Virginia Journal of International Law 405.

${ }^{66}$ eg Sandel, Justice (n 55) 147-51.

${ }^{67}$ See notes and accompanying text beginning at $\mathrm{n} 44$ above.

${ }^{68}$ L Fuller and W Perdue, Jr, 'The Reliance Interest in Contract Damages, Parts 1 and 2' (1936) 46 Yale Law Journal 52, 62. 
then breach should never expand that liability beyond the value we place on that promise. Thus, promise is not an act that can, if breached, inflict harm that must be compensated but, rather, it is an assumption of limited liability. A more reciprocal view of the institution places promissory harm nearer to the centre ${ }^{69}$ and might downgrade the breacher's original promise as having much limiting value once she has breached that promise. At least in relational contract settings, perhaps one surrenders one's right to the benefit of the bargain when one breaches that bargain.

One can get a good sense of the contrasting perspectives on the connection between breach and the original bargain in R3RUE's commentary about Bush $v$ Canfield, ${ }^{70}$ a well-known restitution case where the loser had made a down payment of $\$ 5,000$ in a goods contract where the contract price was $\$ 14,000$ and the goods turned out to be worth only $\$ 11,000$. The seller breached by non-delivery and subsequently resisted the loser's claim for the $\$ 5,000$ down payment, maintaining that the loser's loss on the bargain should be deducted leaving the buyer's refund claim at $\$ 2,000$. The court rejected this proposition. This outcome seems very intuitive and nearly self-evident. But how one explains it can reflect powerfully the vision one has for contract law.

R3RUE would follow precedent and permit Bush to get his $\$ 5,000$ back, undiminished by the consequences of his bad bargain. It does so through its remedy in Section 37 called 'rescission'. But it seems to be a grudging acceptance of this universally followed precedent, embraced by the Article 2 of the Uniform Commercial Code since its inception. ${ }^{71}$ Comment b to R3RUE $§ 37$ explains:

\footnotetext{
${ }^{69}$ Harm done through promising is directly compensated through promissory estoppel even if the promisor did not intend to make a binding commitment. See, eg Ricketts v Scothorn, 77 NW 2d 365 (NE 1898).

${ }^{70}$ Bush v Canfield, 2 Conn 485 (CT 1818).

${ }^{71}$ The specific facts of Bush would today be controlled by Art 2 of the Uniform Commercial Code. UCC $\S$
} 
In theory, and on rare occasions in practice, rescission pursuant to $\S 37$ permits a plaintiff who has paid in advance for a defaulted performance to recover an amount exceeding compensatory damages. See Illustrations 1-2 [Illustration 2 uses the essential facts of Bush v Canfield]. Such outcomes are rare, because a prepaid seller will almost never forfeit a profit that might be earned, at the seller's option, by performing the contract or simply releasing the buyer. The striking results of Illustrations 1-2 are the fortuitous consequence of the law's adherence to a simple rule rather than a complex one. The simple rule is that a plaintiff who seeks only the return of a prepaid price, or return of property in specie, will not (for reasons of both fairness and economy) be put to the burden of proving damages from the defendant's breach. There is no comparable windfall to the plaintiff if the sequence of performance is reversed because rescission is not available as a remedy for a payment default. ${ }^{72}$

Note the underlying assumptions: that expectation damages (derived from the original bargain) are compensatory; that allowing the plaintiff to recover in excess of the bargain is 'striking'; and that damages in excess of expectation are a 'windfall'.

In this vision, the contract once struck has permanently shifted the risk, survives intact, and is independent of performance; breach - and the violation of the reciprocity norm that breach may represent - has little or no role to play. Indeed, but for the administrative convenience that produced Bush v Canfield's 'striking windfall', one would imagine a policy view that would hard-wire the deal Bush and Canfield stuck and return to Bush only the $\$ 2,000$ that was left after deducting his self-inflicted loss on the bargain.

One holding such a strong view of the significance of the original-but breached-bargain might also question or reject the proposition suggested earlier that, were the loser to approach the winner in the midst of performance for a concession, the best outcome would be an adjusted contract. Having played the game at contract formation, for all intents and purposes, the game is over. Having legitimately 'won' at the

2-711(1) permits a buyer in all cases of seller breach to recover 'so much of the price as has been paid'.

${ }^{72}$ R3RUE $\$ 37 \mathrm{cmt} \mathrm{b}$ (emphasis added). 
outset by making a good bargain, the winner should have little reason to make a concession to the loser.

Apart from the convenience of remedy, should the fact of breach itself matter in Bush $v$ Canfield? A sharply contrasting vision of Bush can be seen in the work of Professor George Palmer, a well-known and dominant voice in restitution in the mid to late twentieth century, who wrote a full-throated defensece of the traditional losing contract rule eventually embraced by Restatement (Second) of Contracts $\S 373$ :

Certainly on those facts it is difficult to see the justice of allowing the seller to retain $\$ 3,000$ of the amount received from the buyer, on the plea that the buyer would have lost this amount if the seller had performed a contract which in fact he did not perform. The seller gave nothing in exchange for the $\$ 3,000$ except a broken promise and the principle of unjust enrichment surely is applicable. If the buyer had made no payment and had been the party who repudiated the contract, the seller could have recovered $\$ 3,000$ damages for loss of his bargain. It would be curious indeed for the seller to obtain the same advantage when he is the one guilty of breach. ${ }^{73}$

Significantly, the Reporter's view, compared to Professor Palmer's, is quite different:

In reality, however, the seller 'gave' the essence of what he undertook to give: He made himself liable for flour for future delivery, at a fixed price, giving the buyer an enforceable right to any profit that might be produced by a market advance. In exchange, the seller obtained the mirror-image to the buyer's contractual position: an enforceable right to any profit produced by a market decline. Because the seller's risk was the price of the seller's potential profit, it can hardly be said that the seller, having borne the risk, is unjustly enriched if he obtains the reward. ${ }^{74}$

\footnotetext{
${ }^{73}$ G Palmer, 'The Contract Price as a Limit on Restitution for a Defendant's Breach' (1959) 20 Ohio State

Law Review 264, 267.

${ }^{74}$ Kull, 'Restitution as a Remedy' (n 28) 1484.
} 
Contract, in this latter view, is a matter of individual risk-taking and risk-fixing that occurs at contract formation. The parties are each betting against one another rather than trying to accomplish something through collective effort. The values set at this point are largely immutable and expectation damages are the full equivalent of a contract performed rather than breached. This view may be sound with respect to bets or swaps where there is no performance contemplated other than the payoff; it becomes increasingly implausible as contracts proceed from bets to highly relational contracts such as construction contracts.

In Palmer's vision of contract remedies, breach matters; a promise that is breached is different from a promise that has not been breached. If one views the return of the full prepayment as 'extra' compensation, or as 'supracompensatory' to the party who has made a losing bargain, ${ }^{75}$ perhaps this is in implicit recognition (and a form of quantification) of the reciprocity norm that was violated by the defendant. It should matter little whether the loser gave cash or services prior to the winner's breach. And, since the losing plaintiff seeks only the value of what the defendant received, not necessarily his entire reliance expenditure, the winner is protected against the unlimited and unascertainable risk that a reliance-damages-without-deduction rule would supply.

In giving strong lip service to the contract-as-liability-limit position, the thrust of the commentary to $R 3 R U E$ 's rules gives a primacy to contract law, ${ }^{76}$ tends to enshrine the original bargain of the parties (and the limitations to liability that the bargain might provide), and tends to reduce the significance of breach in actually altering the economic exchange created when the parties struck their contract. In that respect, R3RUE echoes

\footnotetext{
75 See Wilkinson-Ryan and Hoffman, 'Breach is for Suckers' (n 47) 1143.

${ }^{76} R 3 R U E$ Introductory Note 2 to $§ 37$; see also R3RUE $\S 38 \mathrm{cmt}$ a.
} 
the sentiments of modern scholars who lean heavily on law and economics analysis and who are inclined toward a non-reciprocal, contract-as-promise vision of contract law.

Beginning with the free market economic theories championed principally by the University of Chicago (and marketed by its most vociferous spokesperson, Milton Friedman), the related political rhetoric of Margaret Thatcher and Ronald Reagan, and the relentless outpouring of judicial opinions and academic writing by Richard Posner, those views have been promoted on many fronts, have gained considerable ground since the mid 1970s, and may well dominate contemporary contract scholarship. The less individualist, more reciprocal way that earlier scholars thought and wrote about contract problems provided a context for the Restatement (Second) of Contracts; the work of later scholars provided a context for R3RUE. To even the casual observer, the context against which we think about contract law has changed dramatically during the last 25 years and it would be surprising if this context did not affect how contract law is perceived. While this cannot offer normative support for the new losing contract rule, it certainly contributes to our understanding of how it came to be.

\section{How Might the New Rule Fare in the Courts?}

The driving forces behind the new losing contract rule appear to have been instrumental analyses suggesting that the pre-existing rule was inefficient and a view of contract law that saw the breacher's promise (as quantified by the expectation damages system) as providing limitations on the liability that a breacher should shoulder for breaching a contract. Section II suggested that the instrumental effect of contract rules depends on the contractual context, that their operation as incentives in relational contract settings may range from non-existent to extremely small, and in both cases are likely drowned out by other forces. That Section also suggested that instrumental analysis in this context is, in 
any event, extremely malleable and critically depends on assumptions about complex human behaviour for its predictive power. Actual, empirically-based human behaviour may well be different than (or in some cases, perhaps opposite to) that assumed by those supporting a change in the traditional rule and might well support the older rule itself. That Section concluded by suggesting that an instrumental analysis in this highlyrelational context was sufficiently inconclusive as to actually suggest support for the old rule, developed as it was by courts working in the complex contexts that are assumed away in the process of creating a normative instrumental analysis.

Section III argued that a particular vision of contract law and of its primacy over overlapping systems (here, the restitution system) may have driven the rule change, despite case law that remained essentially unchanged. But views of what contract law 'is' change, with a 'contract-as-promise' view dominating the late nineteenth century into the early twentieth, ${ }^{77}$ a far fuzzier view ushered in by the legal realists that included (thanks to Ian Macneil and Stewart Macaulay among others) a recognition of 'contract as relation' that gained many adherents during the twentieth century, and a re-awakened 'contract-aspromise' view gathering momentum in the 1980s. It may not be easy to form an apolitical normative judgment about the losing contract rule when that judgment is inevitably and perhaps imperceptibly affected by our ideological beliefs about what contract law (which turns out, to the surprise of many, to be extremely value-laden) should do.

This Section considers the question of whether the new rule will be embraced by the courts in the kinds of cases where it will arise. It will also briefly consider whether the new rule might have effects outside the litigation system.

The 'contract rate rule' proposed in $R 3 R U E$ has been around for a very long time, is intuitively satisfying, and is probably quite well known. But nonetheless it has been

\footnotetext{
${ }^{77}$ This was, of course, the 'contract' that Grant Gilmore declared 'dead' in G Gilmore, The Death of Contract (Columbus, Ohio State University Press, 1974).
} 
widely rejected by twentieth-century courts. ${ }^{78}$ The staying power in the courts of the traditional 'reasonable value rule' is its central puzzle. If $R 3 R U E$ 's solution will prove unattractive to judges deciding complex cases, the 'contract rate rule' may ultimately fail to gain judicial adherents and thereby become dead letter. This may be particularly true where there is ample precedent in the case law and support in the Restatement (Second) of Contracts for the older approach. In our system, the pressure of work provides strong incentives to judges to follow precedent rather than attempt to explain why a new rule is better.

Despite the primacy-of-contract rhetoric in $R 3 R U E$ 's commentary, ${ }^{79}$ as developed earlier, the 'contract rate rule' proposed in $\S 38$ actually does take breach (and some of Professor Palmer's view) ${ }^{80}$ into account, albeit in a complex way. Section 38(2)(b) provides that a plaintiff may recover for breach of contract:

(b) the market value of the plaintiff's uncompensated contractual performance, not exceeding the price of such performance as determined by reference to the parties' agreement. ${ }^{81}$

When the plaintiff sues for reasonable value conferred, this provision limits the plaintiff to the proportion of the total price represented by the amount of work actually done under

\footnotetext{
${ }^{78}$ See Palmer, Law of Restitution (n 21).

${ }^{79}$ The logic of that rhetoric would bring us a rule that deducted the loser's entire loss from a recovery of the benefit conferred on the breaching winner. See Mather, 'Restitution as a Remedy' (n 15) 48. As developed here, that logic does not lead either to the contract rate rule stated in $\S 38$ or to the price cap rule that may in many cases substitute for it.

${ }^{80}$ Professor Palmer is quoted in the body text, above p XX; compare R3RUE's commentary that captures some of Professor Palmer's view, below n 82 and accompanying text.

${ }^{81} R 3 R U E \S 38(2)(\mathrm{b})$ (emphasis added).
} 
the contract. To the extent the loser had perverse incentives to induce the winner to breach - so he could get a better recovery than would be the case if he were found to be the breacher-those remain incentives under the new rule (since the recovery still depends on who is held to be the breacher), but to a lesser extent.

In amplifying this compromise rule, the commentary explains:

If the rule were otherwise (so that ... the whole of the plaintiff's expected loss from performance were deducted from the value of his interrupted performance), the defendant would be in the position of imposing a unilateral modification or novation, on the terms most favourable to himself, and of doing so, moreover, by breach rather than by negotiation. $^{82}$

While this compromise position may be intuitively appealing and the rule is found in Article 2 of the Uniform Commercial Code for goods contracts, nearly all of which are easily divisible, ${ }^{83}$ the context in which these cases are likely to come up suggest serious problems with the apportionment required to apply the new rule. Indeed, it seems quite likely that the new rule cannot easily be applied at all in the relational settings where it will be called on to perform.

Even in those construction contract cases where some unit rate is stated, a realworld context would suggest that the parties did not intend to apportion their actual performances in the way the stated rate might suggest. In making this point, Professor Palmer wrote:

\footnotetext{
${ }^{82}$ R3RUE $§ 38 \mathrm{cmt} \mathrm{d}$.

${ }^{83}$ UCC § 2-607(1) (buyer pays for goods accepted at the 'contract rate').
} 
Almost without exception such contracts are treated as entire ... This is true even though the whole contract price is based on a price for each unit of work done and the units are capable of precise measurement, for example, so much for each running foot of street graded or each yard of earth excavated. It is evident that this recognizes the realities of the business arrangement - it is not likely, for example, that a contractor would arrange his working schedules and marshal his labor force and equipment at the site to grade one hundred feet of street at the unit price agreed on for more than four thousand feet. ${ }^{84}$

While the $R 3 R U E$ rule may be intuitively satisfying, apportioning the contract price when the parties' agreement does not lend itself to divisability seems both intrusive and a violation of the parties' intent. Their contract was for an entire performance for an entire price, not the fraction of either. Perhaps this can partially explain why Kehoe $v$ Rutherford, ${ }^{85}$ a very well-known case ${ }^{86}$ that used a percentage rule, and on which the $R 3 R U E$ rule is based, was not widely followed in the twentieth century. In complex cases, the apportionment approach will be very difficult to implement ${ }^{87}$ and will likely be no truer to the parties supposed intent than is the traditional rule that simply awards reasonable value. The commentary to the new rule seems to recognize this and suggests that, when apportionment is not possible, courts should simply cap the reasonable value recovery with the contract price. ${ }^{88}$

This may suggest that the real rule that will be available in the complex environments that gave rise to the traditional rule is the contract 'price-cap rule', not the more intuitively-satisfying 'contract rate rule' supported by the commentary to R3RUE $\S$

\footnotetext{
${ }^{84}$ Palmer, Law of Restitution (n 8) $§ 4.4$ pp 404-405.

${ }^{85}$ Kehoe v Rutherford, 27 A 912 (NJ 1893).

${ }^{86}$ The case appears in many Contracts casebooks including (of course) S Macaulay and others, Contracts:

Law in Action, vol 1, 3rd edn (Charlottesville, Lexis, 2011) 185.

${ }^{87}$ In most relational contract settings, both the question whether apportionment is appropriate and what the correct apportionment is will (and should) be hotly contested issues.

${ }^{88}$ See the illustrations to R3RUE $§ 38$, in particular Illustrations 14 and 15.
} 
38(2)(b). This 'price-cap rule' rests on the normative proposition that the winner should never be required to pay more than was explicitly agreed to in the contract.

But capping a reasonable value award by the contract price is even less true to the parties' supposed intent. Indeed, allowing reasonable value up to the contract price, while true to a policy of protecting the winner from paying more than she explicitly promised for the whole performance, may be otherwise incoherent. The big-loser plaintiff who has conferred a small part of the bargained-for benefit receives the same recovery (the contract price) as the small-loser plaintiff who has conferred a much larger part of the work. While one cannot know why an intuitively satisfying Kehoe rule was not widely embraced by the courts, one reason may be that, when faced with the complexities of litigation involving partially-performed contracts, the Kehoe rule was simply unworkable and the alternative of capping a reasonable value award with the contract price seemed an even less satisfying judicial response to the winner's breach of contract than the traditional, uncapped, alternative.

While the inertia of the past (and precedent) might suggest that modern courts, too, might reject the new rule, it is hazardous to project twenty-first century judicial receptivity from twentieth-century decisions. Section 38 will give modern courts some secondary authority to cap a recovery at the contract price, though the main explanation for the rule is the far more satisfying (to some) contract-rate rule. And while the price-cap outcome is (perhaps) the least coherent approach when measured against likely party intent, it may be appealing to courts who would view contract as a liability-limiting device. Our courts are also a product of our modern times and might well be more receptive to a contract-as-promise view of the situation than were earlier courts that considered expectation damages as simply one of many ways the legal system might legitimately respond to a breach of contract.

What about the effects of the new rule those who perform contracts? It seems extremely unlikely that the parties to the kinds of contracts involved here will know of the 
new rule, at least until the first case is litigated and the new rule implemented within it. But even if they were to know of the new rule, and even if the new rule's incentive effects (whatever they may be) were not overwhelmed by the other motivational forces operating in the context of these complex contracts, the parties' strategic decision-making within their contract has actually been further complicated by the new rule. As before, it will be extraordinarily difficult for the parties to an ongoing relational contract to predict who the court will hold to be the first material breacher (and under the new rule, it will still matter). With the announced new rule, it will also be very difficult to predict which rule ('reasonable value rule', 'price-capped rule', or 'contract rate rule') the court will use once it decides the material breach question. The added uncertainty may have the paradoxical effect of keeping relational contracts together by making what will happen if either party withdraws even more unpredictable. ${ }^{89}$ While it would not be a welcome conclusion for those who laboured hard to find the 'right' solution to the losing contract problem, on this basis one might perhaps proclaim the rule 'a success'.

For the contract system more generally, 'success' will be in the eye of the beholder. Quite clearly the new rule further enshrines a particular view of contract law and, in the process, contributes to the marketing of that view. Those who already hold that view will applaud this affirmation of their view, and those now being educated will see additional evidence that it is the way to think about contract law.

But the fascination of this subject is that there always are, and always have been, more ways than one to look at it. In concluding this Section, it is worth recalling a famous passage from Grant Gilmore's The Death of Contract:

\footnotetext{
${ }^{89}$ If, by chance, the parties knew about the uncertainty that would follow if one or the other breached the contract, they might well liquidate damages or limit liability at the outset, an outcome that would be seen by many as the best alternative.
} 
We have become used to the idea that, in literature and the arts, there are alternating rhythms of classicism and romanticism. During classical periods, which are, typically, of brief duration, everything is neat, tidy and logical; theorists and critics reign supreme; formal rules of structure and composition are stated to the general acclaim ... But the classical aesthetic, once it has been formulated, regularly breaks down in a protracted romantic agony. The romantics spurn the exquisitely stated rules of the preceding period; they experiment, they improvise; they deny the existence of any rules; they churn around in an ecstasy of self-expression. At the height of a romantic period, everything is confused, sprawling, formless and chaotic — as well as, frequently, extremely interesting. Then, the romantic energy having spent itself, there is a new classical reformulation—and so the rhythms continue. ${ }^{90}$

We have probably been in another 'classical period' since the 1980 s, but we now have a new generation of researchers, following Macaulay's lead, who are challenging theoretical conclusions with real-world observations. There will be, no doubt, many candidates in the new generation of empirical scholars for the title 'Lord High Executioner of the Contract is Dead Movement' that Gilmore conferred on Macaulay at the start of his book. ${ }^{91}$ It will only be a matter of time before they work their magic.

\section{Conclusion}

Stewart Macaulay began his long career with a 1959 article that wondered whether the law of restitution could be understood without its context. From that first effort, he proceeded to a career - and helped begin a tradition - of empirical examination of the many contexts in which the law is used. His many studies might well be described as unsettling: repeatedly, they suggest that real parties in real situations do not behave as the

\footnotetext{
${ }^{90}$ Gilmore, The Death of Contract (n 77) 111-12.

${ }^{91}$ ibid fn 1.
} 
'rational' people we might hope, imagine or hypothesize them to be. Reading Macaulay would make one scoptical that theory could ever accurately capture or describe a coherent picture, or that rules could have reliably predictable effects on those they aim to affect.

This examination of the losing contract rules - the traditional one found in the Restatement (Second) of Contracts and the new one found in the new Restatement (Third) of Restitution - extends Macaulay's call for 'context' in an effort both to better understand why the rule changed, and to predict whether it will be a successful change. It has suggested that the normative case for the new rule is, ultimately, contingent on behavioural predictions that may be false, and on an idea of contract law that is debatable and perhaps ideological. On this basis, one could argue that the proponents of change have not met their normative burden, and that the courts who have worked in the thicket of relational contracts are more likely to have got it 'right' than have the theorists.

The new complexity that the added rules contribute to predicting legal outcomes may have the effect of dampening party enthusiasm for ending their contracts and, instead, prompting them to work things out rather than resort to litigation. However one views that as an outcome, it may mean that we will not know for a long time whether the new rule will be well-received or rejected in the courts. ${ }^{92}$ And given the cyclical nature of our views of contract law and of the expanding work of Macaulay-inspired empiricists, the 'contract law' that has been the predicate and context for the R3RUE rule may be 'dead' before we find out.

\footnotetext{
${ }^{92}$ Actually, given the replacement of much contract litigation with arbitration, we may never know. See C Knapp, 'Taking Contracts Private: The Quiet Revolution in Contract Law' (2002) 71 Fordam Law Review 761.
} 


\section{Bibliography}

Axelrod, R, The Evolution of Cooperation (New York, Basic Books, 1984).

Ayres, I and Gertner, R, 'Filling Gaps in Incomplete Contracts: An Economic Theory of Default Rules' (1989) 99 Yale Law Journal 87.

Barnett, R, 'A Consent Theory of Contract' (1986) 86 Columbia Law Review 269.

Corbin,A, Corbin On Contracts, vol 5 (St Paul, West Publishing, 1950).

Eisenberg, M, 'Why There is No Law of Relational Contracts' (2000) 94 Northwestern University Law Review 405.

Fried, C, Contract as Promise: A Theory of Contractual Obligation (Cambridge, Harvard University Press, 1981).

Fuller, L and Perdue, Jr, W, 'The Reliance Interest in Contract Damages, Parts 1 and 2' (1936) 46 Yale Law Journal 52.

Gegan, B, 'In Defense of Restitution: A Comment on Mather, Restitution as a Remedy for Breach of Contract: The Case of the Partially Performing Seller' (1984) 57 Southern California Law Review 723.

Gergen, M, 'Restitution and Contract: Comments on the Third Restatement' (2005) 13 Restitution Law Review 224.

__, 'Restitution as a Bridge over Troubled Contractual Waters' (2002) 71 Fordham Law Review 709. 
Gilmore, G, The Death of Contract (Columbus, Ohio State University Press, 1974).

Gordon, R, 'Macaulay, Macneil, and the Discovery of Solidarity and Power in Contract Law' (1985) 1985 Wisconsin Law Review 565.

Hanson, J and Yosifon, D, 'The Situation: An Introduction to the Situational Character, Critical Realism, Power Economics, and Deep Capture' (2003) 152 University of Pennsylvania Law Review 129.

Hill, C, 'Bargaining in the Shadow of the Lawsuit: A Social Norms Theory of Incomplete Contracts' (2009) 34 Delaware Journal of Corporate Law 191.

Hoffman, D and Wilkinson-Ryan, T, 'Breach is for Suckers' (2010) 63 Vanderbilt Law Review 1003.

Holmes, Jr, OW, The Common Law (Boston, Little, Brown \& Co, 1881).

Hyland, R, 'Pacta Sunt Servanda: A Meditation' (1994) 34 Virginia Journal of International Law 405.

Jiminez, M, 'The Value of a Promise: A Utilitarian Approach to Contract Law Remedies' (2008) 56 UCLA Law Review 59.

Kahan, D, 'The Logic of Reciprocity: Trust, Collective Action, and Law' (2003) 102 Michigan Law Review 71.

—_ 'Signaling or Reciprocating: A Response to Eric Posner's Law and Social Norms' (2002) 36 University of Richmond Law Review 367.

Knapp, C, 'Taking Contracts Private: The Quiet Revolution in Contract Law' (2002) 71 Fordam Law Review 761.

Kull, A, 'Rescission and Restitution' (2006) 61 Business Lawyer 569. 
__, 'Restitution as a Remedy for Breach of Contract' (1994) 67 Southern California Law Review 1465.

Laycock, D, Modern American Remedies, 4th edn (New York, Aspen Publishing, 2010).

Llewellyn, K, The Common Law Tradition: Deciding Appeals (Boston, Little, Brown \& Co, 1960).

__, 'What Price Contract' (1931) 40 Yale Law Journal 704.

Macaulay, S, 'The Use and Non-Use of Contracts in the Manufacturing Industry' (1963) 9 Practical Lawyer 14.

—_, 'Restitution in Context' (1959) 107 University of Pennsylvania Law Review 1133.

Macaulay, S and others, Contracts: Law in Action, vol 1, 3rd edn (Charlottesville, Lexis, 2011).

Macneil, I, 'Efficient Breach of Contract: Circles in the Sky' (1982) 68 Virginia Law Review 947.

Mather, H, 'Restitution as a Remedy for Breach of Contract: The Case of the Partially Performing Seller' (1982) 92 Yale Law Journal 14.

Palmer, G, Law of Restitution (Wolters Kluwer).

—_, 'The Contract Price as a Limit on Restitution for a Defendant's Breach' (1959) 20 Ohio State Law Review 264.

Prosser, W, 'Assault Upon the Citadel' (1960) 69 Yale Law Journal 1099. 
Saiman, C, 'Restating Restitution: A Case of Contemporary Common Law Conceptualism' (2007) 52 Villanova Law Review 487.

Sandel, M, Justice: What's the Right Thing to Do? (New York, Farrar, Straus, and Giroux, 2009).

Shapo, M, 'In Search of the Law of Products Liability: The ALI Restatement Project' (1995) 48 Vanderbilt Law Review 631.

White, A, 'Behavior and Contract' (2009) 27 Minnesota Journal of Law and Inequality 135.

Williamson, O, 'Transaction Cost Economics: The Governance of Contractual Relations' (1979) 22 Journal of Law and Economics 233.

Woodward, R and Woodward, W, 'Exemptions as an Incentive to Voluntary Bankruptcy: An Empirical Study' (1983) 57 American Bankruptcy Law Journal 53.

Woodward, Jr, W, 'Contractarians, Community, and the Tort of Interference with Contract’ (1996) 80 Minnesota Law Review 1103. 